\title{
KADAR HORMON PROGESTERON PADA REMAJA PUTRI YANG MENGALAMI PREMENSTRUAL SYNDROME DI PESANTREN DARUL ARQAM MAKASSAR
}

\section{The analysis of hormone progesterone in adolescent teens the experienced premenstrual syndrome in darul arqam pesantren of Makassar}

\author{
Hukmiyah Aspar ${ }^{1}$, Idha Farahdiba ${ }^{2}$ \\ AKBID Pelamonia Makassar \\ hukmiyahaspar@gmail.com
}

\begin{abstract}
Premenstrual syndrome can lead to depression which can sometimes bring up feelings of wanting to commit suicide, even the desire to commit violence on themselves or on others. The purpose of this study was to determine the levels of Progesterone Hormone in Young Women Experiencing Premenstrual Syndrome. The method used is cross sectional. Selection technique technique used is purposive sampling with sample number 50 people (25 PMS and 25 who are not PMS). Actions performed with blood sampling 5 days before menstruation as much as 5-10 cc by using Enzyme Linked Immuno Sorbent Assay (ELISA) kit. Normally distributed data were tested using unpaired parametric $t$ test and nondistributed data were tested using non parametric test Mann Whitney $U$. The results showed that 50 respondents comprised 25 PMS and 25 non-PMS patients got the mean value of subjects who had progesterone levels whose PMS average value of Progesterone Hormone was $3.78 \mathrm{ng} / \mathrm{mL}$ higher than non-PMS of 2, $57 \mathrm{ng} / \mathrm{mL}$. After the examination and data processed by using $t$ test, obtained Ha accepted and Ho is rejected where the mean value in adolescent PMS is higher than that not PMS with $p=0,048<\alpha=0,05$. This means that there is a significant effect of levels of Progesterone Hormone for STD patients with those not suffering from PMS. Furthermore, PMS experienced mild mean value of the hormone Hormone Progesterone of $4.65 \mathrm{ng} / \mathrm{mL}$ while the average value of Progesterone Hormone a heavy PMS of 3.09 $n g / m L$. This $p$ value $=0,030<\alpha=0.05$ means that there is a significant influence of Progesterone Hormone levels between not PMS, mild PMS and heavy PMS.
\end{abstract}

Keywords : Premenstrual syndrome (PMS), Progesterone Hormone, Girls

\section{ABSTRAK}

Premenstrual syndrome dapat menimbulkan depresi yang terkadang dapat memunculkan perasaan ingin bunuh diri, bahkan keinginan untuk melakukan kekerasan pada diri sendiri ataupun pada orang lain. Tujuan penelitian ini adalah untuk mengetahui Kadar Hormon Progesteron pada Remaja Putri yang Mengalami Premenstrual Syndrome. Metode yang digunakan adalah cross sectional. Tekhnik pemilihan sampel yang digunakan adalah penyampelan purposive dengan jumlah sampel 50 orang (25 PMS dan 25 yang tidak PMS). Tindakan dilakukan dengan pengambilan sampel darah 5 hari sebelum menstruasi sebanyak 5-10 cc dengan menggunakan Enzim Linked Immuno Sorbent Assay (ELISA) kit. Data yang berdistribusi normal diuji dengan menggunakan uji parametric $t$ test tidak berpasangan dan data yang tidak berdistribusi normal diuji dengan menggunakan uji non parametric Mann Whitney U. Hasil penelitian menunjukkan dari 50 responden terdiri 25 yang PMS dan 25 yang tidak PMS didapatkan nilai rata-rata subjek yang memiliki kadar Progesteron yang PMS nilai rata-rata Hormon Progesteron sebesar $3,78 \mathrm{ng} / \mathrm{mL}$ lebih tinggi dibandingkan dengan yang tidak PMS sebesar $2,57 \mathrm{ng} / \mathrm{mL}$. Setelah dilakukan pemeriksaan dan data diolah dengan menggunakan uji $t$, didapatkan Ha diterima dan Ho ditolak dimana nilai mean pada remaja PMS lebih tinggi daripada yang tidak PMS dengan nilai $p=$ $0,048<\alpha=0,05$. Hal ini berarti ada pengaruh yang signifikan kadar Hormon Progesteron bagi penderita PMS dengan yang tidak menderita PMS. Selanjutnya yang mengalami PMS ringan nilai rata-rata hormon Hormon Progesteron sebesar $4,65 \mathrm{ng} / \mathrm{mL}$ sedangkan nilai rata-rata Hormon Progesteron yang PMS berat sebesar 3,09 $\mathrm{ng} / \mathrm{mL}$. Nilai $p=0,030<\alpha=$ 0,05 hal ini berarti bahwa ada pengaruh signifikan kadar Hormon Progesteron antara tidak PMS, PMS ringan dan PMS berat.

Kata kunci : Premenstrual syndrome (PMS), Hormon Progesteron, Remaja Putri

\section{PENDAHULUAN}

Premenstrual

syndrome (PMS)

adalah suatu kondisi yang terdiri atas beberapa gejala fisik, emosi, perilaku yang dialami oleh seorang perempuan sebelum datangnya siklus menstruasi, yang menyebabkan gangguan fungsi dan aktifitas sehari-hari, gejala tersebut akan

Vol. XV No. 2, Desember 2020

DOI: https://doi.org/10.32382/medkes.v15i2.1647 menghilang saat menstruasi tiba (Sylvia, 2010).

Premenstrual syndrome dapat menimbulkan depresi yang terkadang dapat memunculkan perasaan ingin bunuh diri, bahkan keinginan untuk melakukan kekerasan pada diri sendiri ataupun pada orang lain. Selain itu dapat pula muncul 
kondisi dimana seseorang sering terbangun di pagi hari dengan perasaan marah, cemas dan sedih. Tidak jarang depresi kemarahan serta sifat yang agresif yang begitu berlebihan dapat membahayakan bagi wanita tersebut dan lingkungannya. Gejalagejala PMS pada remaja dapat berpengaruh pada produktifitas sehari-hari selain itu dapat pula berdampak pada prestasi akademiknya. Kejadian PMS ini dapat mempengaruhi kegiatan di sekolah misalnya penurunan konsentrasi belajar, terganggunya komunikasi dengan teman serta berdampak pada absensi remaja tersebut.

Berdasarkan laporan WHO (World Health Organization), PMS memiliki prevalensi lebih tinggi di negara-negara Asia dibandingkan dengan negara-negara Barat, hal ini disebabkan negara-negara Barat telah memahami kebutuhan-kebutuhan apa saja yang dibutuhkan oleh tubuh.

Hasil penelitian American College Obstetricians and Gynecologists (ACOG) di Sri Lanka tahun 2012, melaporkan bahwa gejala PMS dialami sekitar 65,7 remaja putri. Hasil studi Mahin Delara di Iran tahun 2012, ditemukan sekitar $98,2 \%$ perempuan yang berumur 18-27 tahun mengalami paling sedikit 1 gejala PMS derajat ringan atau sedang. Prevalensi PMS di Brazil menunjukkan angka 39\%, dan di Amerika $34 \%$ wanita mengalami PMS. Prevalensi PMS di Asia Pasifik, diketahui bahwa di Jepang PMS dialami oleh $34 \%$ populasi perempuan dewasa. Di Hongkong PMS dialami oleh $17 \%$ populasi perempuan dewasa.

Studi epidemiologi di Asia menunjukkan kurang lebih $20 \%$ dari wanita usia reproduksi mengalami gejala PMS kategori sedang sampai berat. Di Surabaya prevalensi PMS dengan gejala berat $39,2 \%$ dan mengalami gejala ringan $60,8 \%$ (Mery, 2012). Tujuan penelitian ini adalah untuk mengetahui pengaruh hormon Progesteron pada remaja putri yang mengalami premenstrual syndrome.

\section{METODE}

\section{Desain Penelitian}

Penelitian ini menggunakan cross sectional. Peneliti ingin melihat pengaruh kadar progesteron yang ada pada remaja putri yang mengalami premenstrual syndrome.

Populasi dan Sampel

Populasi adalah keseluruhan siswi kelas XI di Pondok Pesantren Darul Arqam Makassar. Sampel dalam penelitian ini adalah siswi kelas IX dengan teknik pemilihan dilakukan dengan kriteria yang ditetapkan yaitu Kriteria Inklusi, Jumlah dan cara pengambilan subjek (untuk penelitian survei) atau bahan dan alat (untuk penelitian laboratorium)

Pengumpulan data yang digunakan pada penelitian ini adalah Persiapan Penelitian, Pendataan Awal, dan Tahap Penelitian. Persiapan penelitian, Pembuatan Lembar catatan harian (LCH) siklus menstruasi dan Pengurusan izin penelitian pada kepala sekolah Pesantren Darul Arqam Makassar, izin penelitian dari komisi etik penelitian kesehatan Fakultas Kedokteran Universitas Hasanuddin RSPTN UH, RSP dr. Wahidin Sudirohusodo. Pendataan awal dilakukan untuk mengetahui jumlah populasi dan besar sampel minimal yang diperlukan dalam penelitian. Tahap penelitian, pada penelitian ini dimulai dengan pengelompokan sampel sesuai dengan kriteria inklusi dan eklusi. Kemudian pengambilan darah sampel, lalu dikumpulkan, diolah dan dianalisis. Selanjutnya penarikan kesimpulan sesuai dengan hasil penelitian.

\section{PENGOLAHAN DAN ANALISIS DATA}

Setelah data terkumpul selanjutnya dilakukan pengelolaan data dengan bantuan komputer program Excell dan SPSS versi 21. Analisis pengaruh hormon progesteron menggunakan ELISA kit pada remaja putri yang mengalami PMS kemudian dilakukan pengelolaan data dengan menggunakan analisis univariabel, bivariabel, dan multivariabel. Hasil analisisnya ditampilkan dalam bentuk narasi maupun tabel distribusi frekuensi.

\section{HASIL}

Pada tabel 1 menunjukkan bahwa dari 25 responden PMS dengan kelompok umur terbanyak 17 tahun yaitu 19 orang (76\%) terendah pada 15 tahun (4\%), sedangkan dari 25 responden yang tidak PMS dengan kelompok umur terbanyak 17 tahun yaitu 23 orang $(92 \%)$ terendah pada 15 dan 16 tahun yaitu 1 orang (4\%), usia 
menarche terbanyak pada responden PMS yaitu 11 tahun sebanyak 15 orang $(60 \%)$ dan terendah 13 tahun sebanyak 2 orang (8\%) sedangkan responden yang tidak PMS usia menarche terbanyak yaitu 13 tahun sebanyak 14 orang $(56 \%)$ dan terendah pada usia 12 dan 15 tahun sebanyak 2 orang $(8 \%)$. Pada indeks masa tubuh responden yang PMS terbanyak pada IMT berlebih yaitu 15 orang $(60 \%)$ dan terendah kurang yaitu 2 orang (8\%) sedangkan responden yang tidak PMS terbanyak normal yaitu 21 orang (84\%) dan terendah kurang dan berlebih yaitu 2 orang (8\%). Pada karakteristik responden yang PMS terbanyak pada kelompok PMS berat yaitu 14 orang (56\%) dan terendah pada PMS ringan yaitu 11 orang (44\%).

Pada tabel 2 menunjukkan bahwa dari 25 responden berdasarkan kelompok gejalayang paling banyak di alamai adalah sulit konsentrasi sebanyak 17 orang $(68 \%)$ dan terendah pada gejala nafsu makan menurun sebanyak 0 orang $(100 \%)$.

Pada tabel 3 menunjukkan bahwa dari 50 responden, 25 yang PMS dan 25 yang tidak PMS didapatkan nilai rata-rata responden yang memiliki kadar Progesteron di mana yang responden yang PMS nilai rata -rata progesteronnya sebesar 3,78 lebih tinggi dibandingkan dengan yang tidak PMS sebesar 2,57. Setelah dilakukan pemeriksaan hormone progesteron dan data diolah dengan menggunakan uji $t$, didapatkan $\mathrm{Ha}$ diterima dan $\mathrm{Ho}$ ditolak dimana nilai mean pada remaja PMS lebih tinggi dari pada yang tidak PMS dengan nilai $p=0,048<\alpha=0,05$. Hal ini berarti ada perbedaan yang signifikan kenaikan progesteron bagi penderita PMS dengan yang tidak menderita PMS.

Pada tabel 4 menunjukkan bahwa didapatkan nilai rata-rata hormon progesteron yang tidak mengalami PMS sebesar 2,57, dan dibandingan dengan yang mengalami PMS ringan nilai rata-rata hormon progesteron sebesar 4,65 sedangkan nilai rata-rata hormon progesteron yang PMS berat sebesar 3.09. Nilai $p=0,030<\alpha=0,05$ hal ini berarti bahwa ada perbedaan signifikan nilai rata antara tidak PMS, PMS ringan dan PMS berat.

\section{PEMBAHASAN}

Vol. XV No. 2, Desember 2020

DOI: https://doi.org/10.32382/medkes.v15i2.1647
Pada penelitian ini menunjukkan bahwa Premenstrual syndrome adalah Kombinasi gejala yang terjadi sebelum haid dan menghilang dengan keluarnya darah menstruasi serta dialami oleh banyak wanita setiap siklus menstruasi yang menyebabkan ia mengalami gangguan dalam fungsi alat reproduksi dan aktifitas sehari-hari.

Hasil penelitian di SMP Negeri 4 kota Malang diperoleh bahwa pemberian pendidikan kesehatan sejak dini pada remaja sangat penting dan salah satu metode yang dapat dipilih adalah metode pendidikan sebaya terhadap pengetahuan remaja mengenal premenstrual syndrome. Dari hasil yang didapatkan tingkat pengetahuan subjek sebelum diberi pendidikan kesehatan sebagian besar berada pada tingkat cukup $(67,7 \%)$ dan sesudah diberi pendidikan kesehatan subjek memiliki tingkat pengetahuan baik $(77,4 \%)$. Berkaitan dengan teori menurut Sarwono (2010), ada dua hal penting menyebabkan remaja melakukan pengendalian diri. Dua hal tersebut adalah, pertama, hal yang bersifat eksternal, yaitu adanya perubahan lingkungan, dan kedua adalah hal yang bersifat internal, yaitu karakteristik di dalam diri remaja yang membuat remaja relatif lebih bergejolak dibandingkan dengan masa perkembangan lainnya (storm and stress period).

Hasil penelitian ini menggambarkan bahwa umur 17 tahun sebanyak 19 orang (76\%) merupakan kelompok responden yang lebih banyak mengalami PMS dan yang tidak mengalami PMS sebanyak 23 orang (92\%), hal ini menandakan bahwa pada umur 17 tahun merupakan usia subur yang rentan terjadinya PMS dan itu akan mempengaruhi kesehatan reproduksinya dalam memperoleh keturunan di masa yang akan datang. Berdasarkan teori Suparman (2011), mengatakan faktor cenderung penyebab PMS adalah usia, Prevalensi PMS sebesar $20-40 \%$ dari seluruh wanita usia reproduksi, rentang demografi usia antara 14-51 tahun. Sumartinah (1991) menyebutkan tentang usia penderita di Indonesia terbanyak antara 25-35 tahun, dengan kecenderungan meningkat insidennya pada golongan usia yang lebih tua.

Usia dewasa telah terjadi kematangan perkembangan emosional, 
dimana perkembangan emosional akan sangat berpengaruh terhadap respon serta tindakan seseorang terhadap status kesehatan, banyak wanita melaporkan mengalami gejala PMS lebih awal dan fakta yang mengungkapkan bahwa sebagian remaja mengalami gejala yang sama dan kekuatan PMS yang sama sebagaimana yang dialami oleh wanita yang lebih tua (Fairus, 2011).

Berdasarkan hasil penelitian karakteristik usia menarche pada responden yang mengalami PMS lebih banyak pada usia 11 tahun (60\%). Menarche merupakan suatu masa perkembangan hormonal dan fisik telah cukup matang untuk dimulainya siklus menstruasi.Umur menarche atau umur pada saat datangnya menstruasi pertama pada remaja putri merupakan suatu pengukuran dalam penelitian pertumbuhan dan perkembangan guna menilai kecepatan pematangan reproduksi individu. Saat ini seorang remaja putri mendapat menstruasi lebih cepat yaitu menarche pada usia 10-12 tahun. Hal ini sejalan dengan penelitian Aminah dkk (2011), yang menunjukkan bahwa PMS lebih banyak terjadi pada kelompok siswa putri dengan usia menarche < 12 tahun (cepat) yaitu 47,17\% dibandingkan dengan dengan usia menarche $\geq 12$ tahun yaitu $19,82 \%$. Remaja dengan usia menarche $<12$ tahun mempunyai peluang untuk terjadi PMS 2,3 kali lebih besar dibandingkan dengan remaja dengan usia menarche $\geq 12$ tahun. Berdasarkan hasil penelitian karakteristik IMT pada responden yang mengalami PMS lebih banyak memiliki IMT berlebih sebanyak 15 orang $(60 \%)$. Hal ini sesuai dengan teori mengatakan bahwa penyebab PMS adalah ketidakseimbangan hormon estrogen dan progesteron yang diantaranya disebabkan oleh obesitas karena kelebihan lemak juga memicu terjadinya PMS (Purwoastuti dkk., 2015). Remaja putri yang obesitas lebih banyak yang mengalami kejadian PMS yaitu sebesar 55,6\% dibandingkan dengan remaja putri yang tidak mengalami obesitas dan terkena PMS di MAN 1 Metro Lampung Timur yaitu sebesar 27,4\%. Hasil penelitian ini sejalan dengan hasil penelitian pada Mahasiswa Akademi Kebidanan Pemerintah Kabupaten Kudus, yang menunjukkan ada hubungan bermakna antara obesitas pada remaja putri dengan PMS hasil uji statistik menunjukan nilai $p$-value $=0,000(p<0,05)$.

Distrubusi responden berdasarkan gejala yang dialami remaja. Hasil penelitian didapatkan dari 50 responden, 25 responden yang PMS dan 25 orang yang tidak PMS, yang mengalami gejala PMS terbanyak pada gejala sulit konsentrasi sebanyak 17 orang (34\%). Hal ini sejalan dengan teori yang mengatakan bahwa gejala umum yang ditemukan pada PMS seperti gangguan kognitif dapat berupa ketidakseimbangan konsentrasi dan bingung (Saryono dkk., 2009). Gangguan somatik berupa mastalgia (nyeri pada payudara), kembung sakit kepala, kelelahan dan insomnia serta gangguan perilaku sosial yaitu konsumsi berlebih karbohidrat (Amelia, 2014).

Analisis perbedaan rata-rata kadar hormon progesteron pada remaja PMS dan tidak PMS. Dari hasil penelitian didapatkan bahwa dari 50 responden 25 yang PMS dan 25 yang tidak PMS didapatkan nilai rata-rata responden yang memiliki kadar hormon progesteron dimana yang responden yang PMS nilai rata-rata hormon progesteronnya sebesar 3,78 lebih tinggi dibandingkan dengan yang tidak PMS sebesar 2,57. Setelah data diolah dengan uji t didapatkan $p=0,048<\alpha=0,05$.

Perbedaan rata-rata kadar hormon progesteron pada remaja tidak PMS, PMS ringan dan PMS berat. Berdasarkan penelitian didapatkan didapatkan nilai ratarata Kadar Hormon progesteron yang tidak PMS sebesar 2,57, yang mengalami PMS ringan nilai rata-rata Kadar Hormon progesteron sebesar 4,65 sedangkan nilai rata-rata Kadar Hormon progesteron yang PMS berat sebesar 3.09. Nilai $p=0,030<\alpha$ $=0,05$. Berdasarkan kriteria diagnostik ACOG untuk PMS Suparman (2011), PMS ringan diagnostik bila semua kriteria terpenuhi baik keluhan somatik, maupun keluhan afektif, sedangkan PMS berat didiagnosis bila pasien mengalami 5 atau lebih keluhan dan termasuk satu dari 4 (keluhan utama seperti perasaan tertekan, tak berguna, pikiran rendah diri yang nyata, kecemasan atau ketegangan yang nyata, perasaan terasingkan atau terpinggirkan, labilitas afek yang bermakna (perasaan mendadak sedih atau menangis, menjadi sensitif terhadap penolakan, dan 
kemarahan atau iritabilitas (Ratikasari, 2005).

\section{KESIMPULAN}

Berdasarkan hasil penelitian diperoleh terdapat perbedaan kadar hormon progesteron pada remaja putri yang PMS, perbedaan kadar hormon progesteron pada remaja putri yang tidak PMS. serta perbedaan kadar hormon progesteron pada remaja putri yang PMS dan tidak PMS dimana nilai mean PMS lebih tinggi dari pada yang tidak PMS.

\section{SARAN}

Kepada setiap perempuan, agar selalu memperhatikan siklus haidnya sejak dini untuk menghindari terjadinya gangguan-gangguan yang berhubungan dengan haid sehingga kejadian premenstrual syndrome dapat diminimalisir.

\section{DAFTAR PUSTAKA}

Amelia C.R. (2014). Pendidikan Sebaya Meningkatkan Pengetahuan premenstruasi pada remaja, e-journal Vol.4 Desember 2014. Diperoleh tanggal 24 Oktober 2016.

Aminah S dkk. (2011). Hubungan Status Gizi dengan Kejadian Premenstruasi Sindrom di Madrasah Aliyah Negeri 4 Jakarta, e Journal Vol. 6 Juni 2011. Diperoleh tanggal 17 Oktober 2016.

Fairus. (2011). Fisiologi Kebidanan, Pustaka Rinma, Yogyakarta.
Mery R. (2012). Jurnal Kesehatan Masyarakat Maret 2013 Vol.7 No.1. Diperoleh tanggal 24 Oktober 2016.

Purwoastuti E. dkk. (2015). Kesehatan Reproduksi dan Keluarga Berencana, Pustaka Belajar, Yogyakarta.

Ratikasari I. (2005). Faktor-faktor yang berhubungan dengan Kejadian Sindrom Premenstruasi pada siswi SMA 112, e-Journal 2015. Diperoleh tanggal 23 Oktober 2016.

Saryono dkk. (2009). Sindrom Premenstruasi, Numed, Yogyakarta.

Sarwono. (2010). Pelayanan Kesehatan Maternal, PT Raja Grafindo Perkasa, Jakarta, 2003.

Sylvia. (2010). Konsep Klinik proses-proses penyakit, Salemba Medika, Jakarta.

Suparman E. (2011). Premenstrual Syndrome, EGC, Jakarta, 2012. 


\section{LAMPIRAN}

Tabel 1. Distribusi Responden Berdasarkan Karakteristik Remaja Putri Yang Mengalami PMS dan Tidak PMS Di Pesantren Darul Arqam Makassar

\begin{tabular}{|c|c|c|c|c|}
\hline \multirow{4}{*}{$\begin{array}{c}\text { Karakteristik } \\
\text { Responden } \\
\text { Usia Remaja }\end{array}$} & \multicolumn{4}{|c|}{ Kelompok } \\
\hline & \multicolumn{2}{|c|}{ PMS } & \multicolumn{2}{|c|}{ Tidak PMS } \\
\hline & $\mathbf{n}$ & $\%$ & $\mathbf{n}$ & $\%$ \\
\hline & & & & \\
\hline 15 tahun & 1 & 4.0 & 1 & 4.0 \\
\hline 16 tahun & 5 & 20.0 & 1 & 4.0 \\
\hline 17 tahun & 19 & 76.0 & 23 & 92.0 \\
\hline Usia Menarche & & & & \\
\hline 10tahun & 2 & 8.0 & 2 & 8.0 \\
\hline 11tahun & 15 & 60.0 & 14 & 56.0 \\
\hline 12tahun & 3 & 12.0 & 7 & 28.0 \\
\hline 13tahun & 5 & 20.0 & 2 & 8.0 \\
\hline IMT & & & & \\
\hline Kurang & 2 & 8.0 & 2 & 8.0 \\
\hline Normal & 8 & 32.0 & 21 & 84.0 \\
\hline Berlebih & 15 & 60.0 & 2 & 8.0 \\
\hline STATUS PMS & & & & \\
\hline Tidak PMS & 0 & 0.0 & 25 & 100.0 \\
\hline Ringan & 11 & 44.0 & 0 & 0.0 \\
\hline Berat & 14 & 56.0 & 0 & 0.0 \\
\hline Jumlah & 25 & 100.0 & 25 & 100.0 \\
\hline
\end{tabular}

Tabel 2. Distrubusi Responden Berdasarkan Gejala yang Dialami Remaja yang PMS di Pesantren Darul Arqam Makassar

\begin{tabular}{lllllll}
\hline Gejala & Tidak & \multicolumn{3}{c}{ Ya } & \multicolumn{3}{c}{ Jumlah } \\
& n & \% & n & \% & N & \% \\
\hline Sedih dan Putus Asa & 22 & 88.0 & 3 & 12.0 & 25 & 100.0 \\
Merasa Tidak Berguna & 23 & 92.0 & 2 & 8.0 & & 100.0 \\
$\begin{array}{l}\text { Cemas dan Tegang } \\
\text { Merasa Tidak Tenang }\end{array}$ & 19 & 76.0 & 6 & 24.0 & & 100.0 \\
Gelisah & 21 & 84.0 & 4 & 16.0 & & 100.0 \\
Sedih dan Menangis & & & & & & \\
Mudah Tersinggung & 18 & 72.0 & 7 & 28.0 & & 100.0 \\
Banyak Marah dan Jengkel & 11 & 44.0 & 14 & 56.0 & 100.0 \\
Malas Melakukan Sesuatu & 14 & 56.0 & 11 & 44.0 & & 100.0 \\
Sulit Konsentrasi & 8 & 52.0 & 12 & 48.0 & & 100.0 \\
Mudah Lelah & 16 & 32.0 & 17 & 68.0 & & 100.0 \\
Nafsu Makan Menurun & 25 & 100.0 & 9 & 36.0 & & 100.0 \\
\hline
\end{tabular}




\begin{tabular}{|c|c|c|c|c|c|}
\hline Makan Banyak Sekali & 24 & 96.0 & 1 & 4.0 & 100.0 \\
\hline $\begin{array}{l}\text { Ingin Memakan Sesuatu } \\
\text { Makanan }\end{array}$ & 20 & 80.0 & 5 & 20.0 & 100.0 \\
\hline Tidur Banyak Sekali & 23 & 92.0 & 2 & 8.0 & 100.0 \\
\hline Rasanya Saya Ingin Teriak & 24 & 96.0 & 1 & 4.0 & 100.0 \\
\hline $\begin{array}{l}\text { Karena Jengkel Saya Ingin } \\
\text { Membanting Benda di Sekitar } \\
\text { Saya }\end{array}$ & 22 & 88.0 & 3 & 12.0 & 100.0 \\
\hline Kepala Saya Sakit & 22 & 88.0 & 3 & 12.0 & 100.0 \\
\hline Pinggang Saya Terasa Sakit & 11 & 44.0 & 14 & 56,0 & 100.0 \\
\hline $\begin{array}{l}\text { Payudara Saya Nyeri atau } \\
\text { Bengkak }\end{array}$ & 14 & 56.0 & 11 & 44.0 & 100.0 \\
\hline Perut Kembung & 23 & 92.0 & 2 & 8.0 & 100.0 \\
\hline Sendi dan Otot Nyeri & 21 & 84.0 & 4 & 16.0 & 100.0 \\
\hline Kenaikan Berat Badan & 24 & 96.0 & 1 & 4.0 & 100.0 \\
\hline Jerawat & 15 & 60.0 & 10 & 40.0 & 100.0 \\
\hline
\end{tabular}

Tabel 3. Tabel Analisis Perbedaan Rata-rata Kadar Hormon Progesteron Pada Remaja PMS dan Tidak PMS Di Pesantren Darul Arqam Makassar

\begin{tabular}{lccc}
\hline Kelompok Remaja & \multicolumn{2}{c}{$\begin{array}{c}\text { Konsentrasi Hormon } \\
\text { Progesteron }\end{array}$} & $\begin{array}{c}\text { Nilai p } \\
\text { (uji } \boldsymbol{t} \text { ) }\end{array}$ \\
\cline { 2 - 3 } & Mean & Std.Deviation & \\
\hline PMS & 3,78 & 1,99 & \multirow{2}{*}{0.048} \\
Tidak PMS & 2,57 & 0,92 & \\
\hline
\end{tabular}

Sumber : Data Primer

Tabel 4. Tabel Analisis Perbedaan Rata-rata Kadar Hormon Progesteron Pada Remaja Tidak PMS, PMS Ringan dan PMS Berat Di Pesantren Darul Arqam Makassar

\begin{tabular}{lccc}
\hline \multirow{2}{*}{ Kelompok Remaja } & \multicolumn{2}{c}{$\begin{array}{c}\text { Kadar Hormon } \\
\text { Progesteron }\end{array}$} & \multirow{2}{*}{$\begin{array}{c}\text { Nilai p } \\
\text { (uji } \boldsymbol{t})\end{array}$} \\
\cline { 2 - 3 } & Mean & Std.Deviation & \\
\hline Tidak PMS & 2,57 & 0,92 & \multirow{2}{*}{0.030} \\
PMS Ringan & 4,65 & 1,83 & \\
PMS Berat & 3.09 & 1,89 & \\
Sumber : Data Primer & & &
\end{tabular}

